\title{
IDENTIFICATION OF THE SOURCE AREAS FOR THE PALEOGENE TURBIDITIC DEPOSITS OF THE PIENIDIAN UNITS IN MARAMURES
}

\author{
CARLO AROLDI ${ }^{1}$
}

\begin{abstract}
The Pienides are structural units formed almost exclusively of deep-water siliciclastic deposits, Middle Jurassic-Oligocene in age, belonging of an oceanic crust-bearing domain. The Pienides form an elongate belt extending from Western Carpathians to Poiana Botizei (Maramureş, northern Romania), which represents the easternmost outcrop of these units in the Eastern Carpathians. Petrographic analyses on sandstones of different nappes combined with sedimentologic studies (depositional systems, palaeocurrents) allow to consider the Inner Dacides (forming the pre-Apulian continental margin) the most probable source unit for most of the siliciclastic successions of the Pienides. The present arrangement of the structural units, geophysical and subsurface data and stratigraphic correlations with analogue sequences from Western Carpathians, allow to frame the Pienides in Maramureş in an overall context of trench-slope basin and the related deposits may be considered as a part of an accretionary prism which developed during the whole Palaeogene.
\end{abstract}

Key words: Eastern Carpathians, Maramureş, Pienides, siliciclastic deposits, turbidite successions.

The Pienidian Units in Maramureş

The Tethyan Suture is represented, in the northern part of the Eastern Carpathians, by a group of units, called the Pienides. The Pienides are formed mainly by deep-water siliciclastic deposits consisting of Middle Jurassic-Oligocene successions, lacking any direct evidence of oceanic crust. The oceanic origin of the Pienides in Maramureş was deduced only by structural considerations based on geophysical and subsurface data and by stratigraphic correlations with corresponding sequences from Slovakia, Poland and Ukraine. The Pienides form an elongate belt, ranging from the Slovakian and Polish Western Carpathians to Poiana Botizei (Maramureş, northern Romania) which represents the easternmost outcrop of this type in the Eastern Carpathians (Bombiță \& Pop, 1991). In the Maramureş area, the Pienides are formed by several cover nappes subdivided in four groups of tectonic units (structurally, from the outermost to the innermost): a) the Măgura Group, formed by Petrova, Leordina and Wildflysch nappes; b) the Pieniny Klippen Zone;

\footnotetext{
1 “Babeş-Bolyai” University, Department of Geology, Str. Kogălniceanu 1, 3400 Cluj-Napoca, Romania.
} 
c) the Botiza and Kricevo units; d) the Băbeşti - Tijacovo Unit (Fig. 1). This latter unit does not outcrop, having been identified only in subsurface, both in Romania and in Subcarpathian Ukraine (Săndulescu et al.,1993).

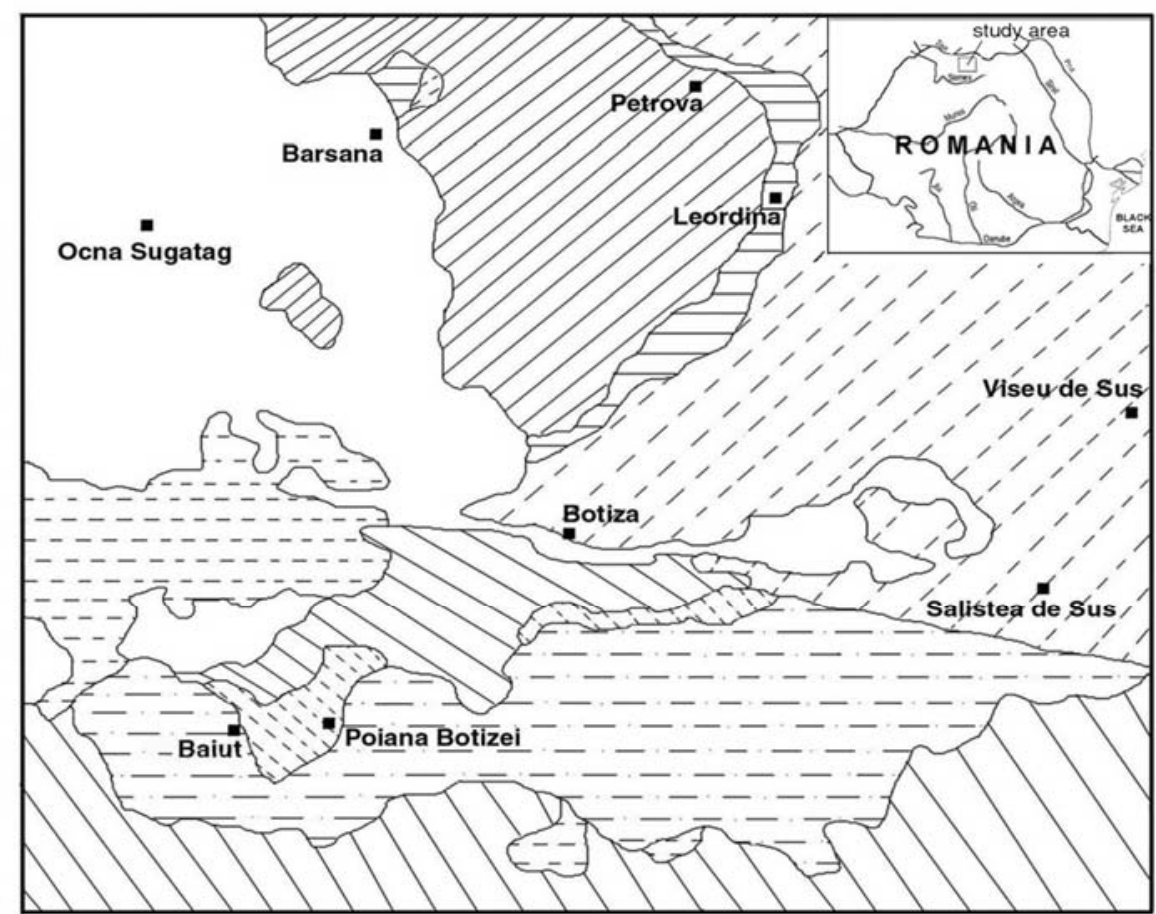

A

B
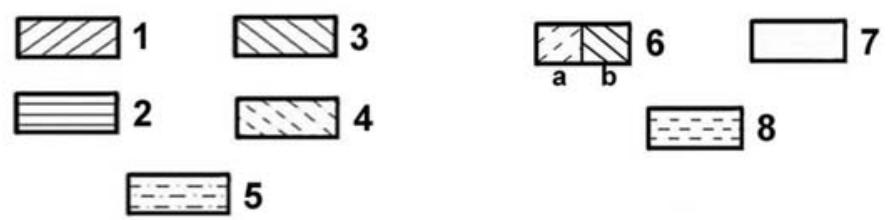

Figure 1 - Structural map of north-western Maramureş, showing the extension of the different tectonic units outcropping in the study area (A-Pienidian Units: 1-Petrova Nappe, 2-Leordina Nappe, 3-Botiza Nappe, 4-Poiana Botizei Klippen Zone, 5-Wildflysch Nappe. B-Other Units: 6-Cover of Dacidian Units, 7-Neogene Basins, 8-Neogene Volcanics).

The structural arrangement of the Pienides records two important tectonic phases. The first one took place during the Latest Cretaceous, with formation of imbrications, while the second one during Burdigalian, with formation of overthrusts which displaced the Pienidian units over the Median Dacides. In particular, during Burdigalian, the displacement of the Pienidian units was constrained by two tectonic lines, the North Transylvanian Fault (which bounds the southern limit of the Pienides) and the Bogdan Vodă Fault (which separates different Pienidian nappes), probably representing former oceanic transform faults. 
Lithologically, the Pienidian Units consist mainly of siliciclastic turbidite successions typically formed by the alternation of sandstone and mudstone layers. These deposits can be grouped in different turbidite systems showing an overall progradational trend, manifested by the presence of thickening and coarseningupward successions and frequent episodes of syn-sedimentary tectonic activity (Aroldi, 2001).

\section{Petrofacies analyses}

Examining data referring to the modal analysis for the Wildflysch Nappe and considering the vertical petrofacies trend, a transition from litharenitic to arkosic types can be observed, being more evident in the samples of the eastern part of the nappe. Such trend, confirmed by the analysis of lithic fragments (Fig. 2), can be explained by a progressive unroofing of a continental crust with sedimentary and fine-grained metasedimentary rocks at the top and granite-gneissic lithotypes in the deeper parts (Plate I, Fig. 1). Data from palaeocurrents confirm a provenance of clastic detritus from W-SW, so that the Inner Dacides, forming the pre-Apulian continental margin of the Palaeogene Pienidian ocean, can be assumed as the most probable source area for clastics.
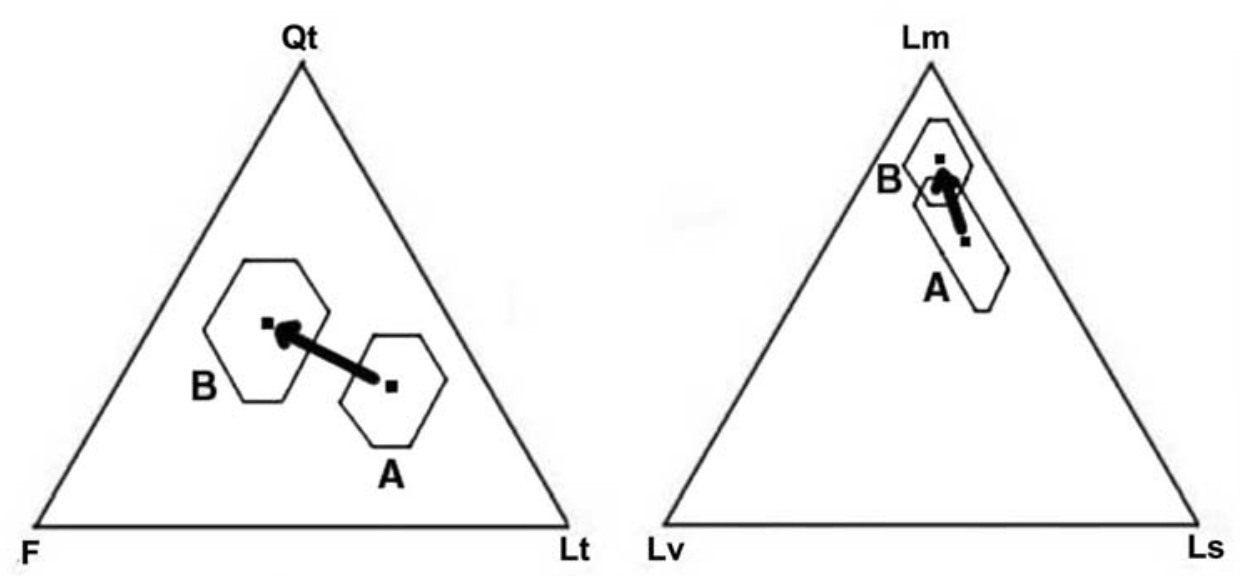

Figure 2 - Modal analyses for the arenites of the Wildflysch Nappe that evidences the progressive unroofing trend in the lithostratigraphic succession $(A=$ Eocene samples, $B=$ Oligocene samples, $Q t=$ total quartz, $F=$ total feldspars, $L t=$ total lithic fragments; $L s=$ sedimentary-metasedimentary lithics, $L m=$ metamorphic-magmatic lithics, $L v=$ volcanic litics).

The sandstones belonging to Petrova and Leodina nappes show petrofacies similar with those of Wildflysch Nappe with less quantity of sedimentary clasts due to reduced supply of carbonate material. This fact, together with similarity in the architecture of the corresponding depositional systems, confirm at least the equivalent 
palaeogeographic position of the Petrova and Wildflysch nappes. The presence of carbonatic debris (Plate I, Fig. 2) and of several calcareous blocks of recifal origin, intercalated in the normal basinal sedimentation of the successions outcropping in the western part of the Wildflysch Nappe, proves the existence of a carbonate platform tectonically active since the Middle Eocene (Aroldi \& Bucur, 2002).

The sandstones of the Botiza Nappe, the innermost outcropping tectonic unit belonging to the Pienides in Maramureş, but also some of the Wildflysch Nappe, show a litharenitic composition with abundant volcanic fragments (Plate II, Fig. 1) and sedimentary clasts of oceanic-domain (radiolarites, limestones with Calpionellae, Plate II, Fig. 2). Palaeocurrent data confirm a provenance of the sediment supply from an innermost area, represented by the buried Babesti-Tijacovo Unit, which shows a typical ophiolitic succession. An alternative possibility can be to consider the sourcing of this material from the Bükk Unit (NE Hungary), in which a volcano-sedimentary succession, belonging to the Middle Triassic Meliata ocean, is exposed.

\section{Location of source areas and paleogeography}

The Inner Dacides, which are equivalent of the Austroalpine Units of the Eastern Alps, represent a portion of the Pre-Apulian continent. They are the most probable source area for clastics of the Pienides in Maramureş, because both sedimentologic and petrographic observations. The Inner Dacides are made up by several superimposed tectonic units, characterised by the presence of a continental basement made of Palaeozoic and pre-Palaeozoic crystalline rocks, covered by PermoMesozoic sedimentary deposits (Săndulescu, 1984). The tectonic boundary between the Inner Dacides and the Pienidian oceanic domain can not be found in the studied area, because the Inner Dacides extend under the Transylvanian and Pannonian basins, hence partially covered by Neogene sedimentary formations and by the Neogene Volcanic Arc. The presence of an extended Palaeocene - Eocene carbonate platform is responsible for the limestone intraclasts found in the arenites and of the chaotic deposits intercalated in the lower part of the Wildflysch Nappe.

The combined petrographic, stratigraphic, tectonic and sedimentological data allow to depict a paleogeographic scenario and a geodynamic model for the Palaeogene evolution of the Pienides in Maramureş (Aroldi, 2003, Fig. 3). This attempt is based on the present arrangement of the structural units, acquired only after the Neogene tectonic displacements. There is few evidence of the presence of ophiolitic complexes in the whole Pienidian Suture Zone in Maramureş. Nevertheless, the presence of analogue units in Eastern Alps and in Western Carpathians, the existence of basic and ultrabasic rocks in the Babeşti-Tijacovo Unit and the existence of oceanic lithoclasts in the arenites of the innermost nappes, prove the existence of an oceanic domain, probably belonging to the Main Tethyan Suture and extending from the Eastern Alps to Maramureş. The existence of an ocean-crust bearing basin in the study area can be framed in an overall context of trench-slope basin and the related deposits can be considered as a part of an accretionary prism which evolved during the whole Palaeogene. 


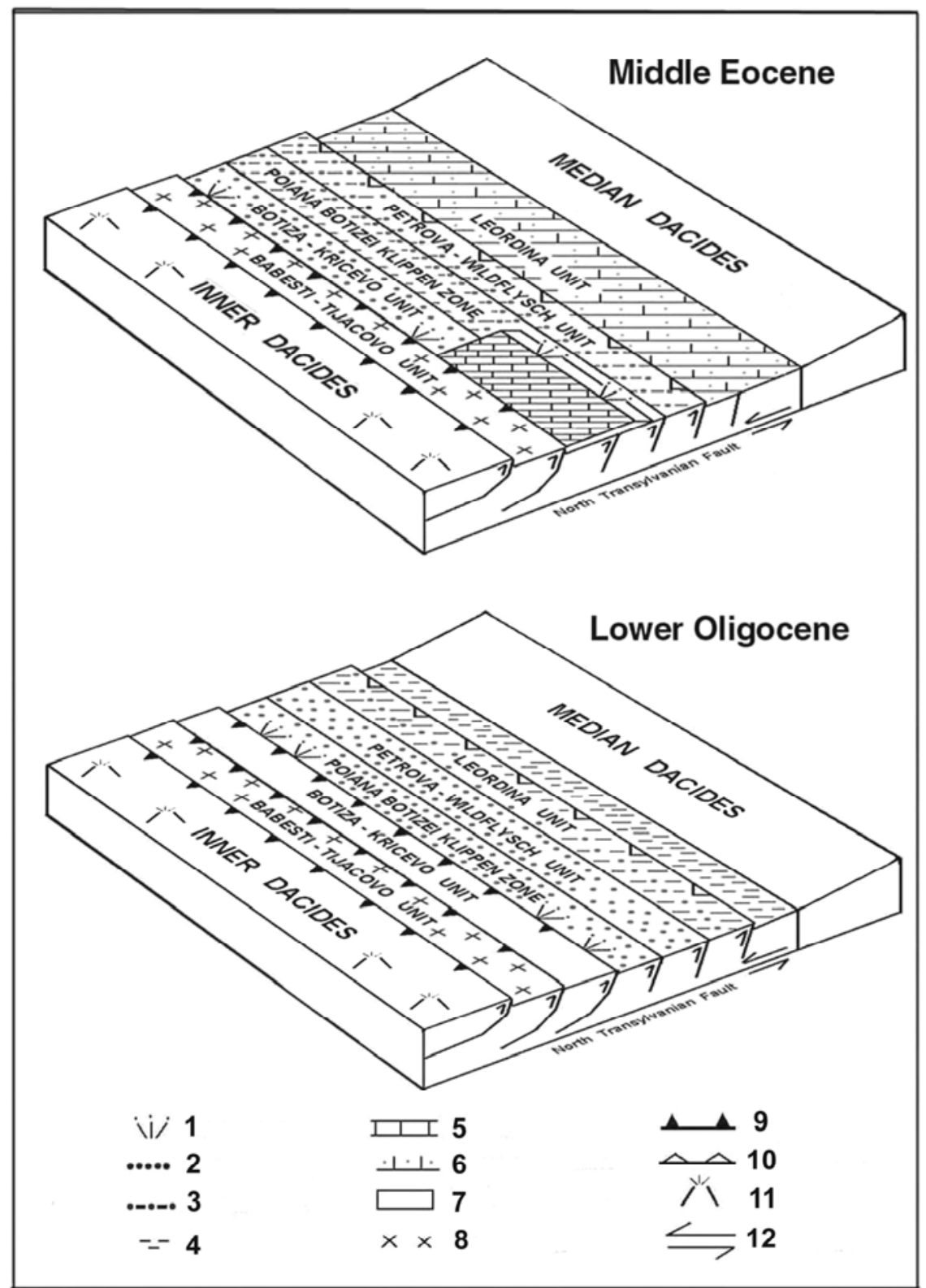

Figure 3 - Palaeogeographic evolution of the Pienidian accretionary prism during Eocene and Oligocene times, showing the basinward progradational trend of the turbiditic facies (1-Points of clastic input, 2-Proximal turbidites 3-Distal turbidites, 4-Pelitic deposits, 5-Carbonate platform, 6-Calcareous turbidites, 7-Crystalline units and their sedimentary cover, 8-Ophiolitic units, 9-Overthrust front, 10-Accretionary front, 11-Volcanism, 12-Main tectonic lines). 


\section{CARLO AROLDI}

\section{REFERENCES}

AROLDI, C. (2001) - The Pienides in Maramureş - Sedimentation, Tectonics and Paleogeography. Presă Universitară Clujană. 156 pp. ISBN 973-8095-77-8.

AROLDI, C., BUCUR, I. I. (2002) - Palaeogene microfacies in some calcareous blocks of the Roaia Formation (Wildflysch Nappe - Maramureş). Studia Universitatis Babeş-Bolyai, Geologia, Special Issue 1, p. 13-30.

AROLDI, C. (2003) - Provenance studies in some Palaeogene turbidites of the Eastern Carpathians (Maramureş-Northern Romania). 22nd IAS Meeeting of Sedimentology, Opatija 2003, Abstract Book, p.6.

BOMBIȚĂ, G., POP, G. (1991) - Mezozoic Formations from Poiana Botizei, Pieniny Klippen Belt of Romania. Geologica Carpathica, vol. 42/3, p. 139-146.

SĂNDULESCU, M. (1984) - Geotectonica României. Editura Tehnică, Bucureşti. 336 pp.

SĂNDULESCU, M., VISARION, M., STĂNICĂ, D., STĂNICĂ, M., ATANASIU, L. (1993) - Deep Structure of the Inner Carpathians in the Maramureş-Tisa Zone. Rom. Journ. Geoph., v. 16, p. 67-76.

\section{Plate I}

Fig. 1 - Arkosic petrofacies, with abundant microcline of magmatic or meso-metamorphic origin, frequent in the Oligocene levels of the Wildflysch Nappe.

Fig. 2 - Mixed carbonatic-siliciclastic arenite (with fragments of Nummulites) in the Eocene levels of the Wildflysch Nappe. Note the high grade of compaction, proved by the reciprocal compenetration of different fragments.

\section{Plate II}

Fig. 1 - Intermediate volcanic fragments, with porphiric-intersertal texture, in a Eocene lithic arenite of the Botiza Nappe.

Fig. 2 - Fragment of a micritic limestone with Calpionellae in a Eocene lithic arenite of the Botiza Nappe. 
Plate I
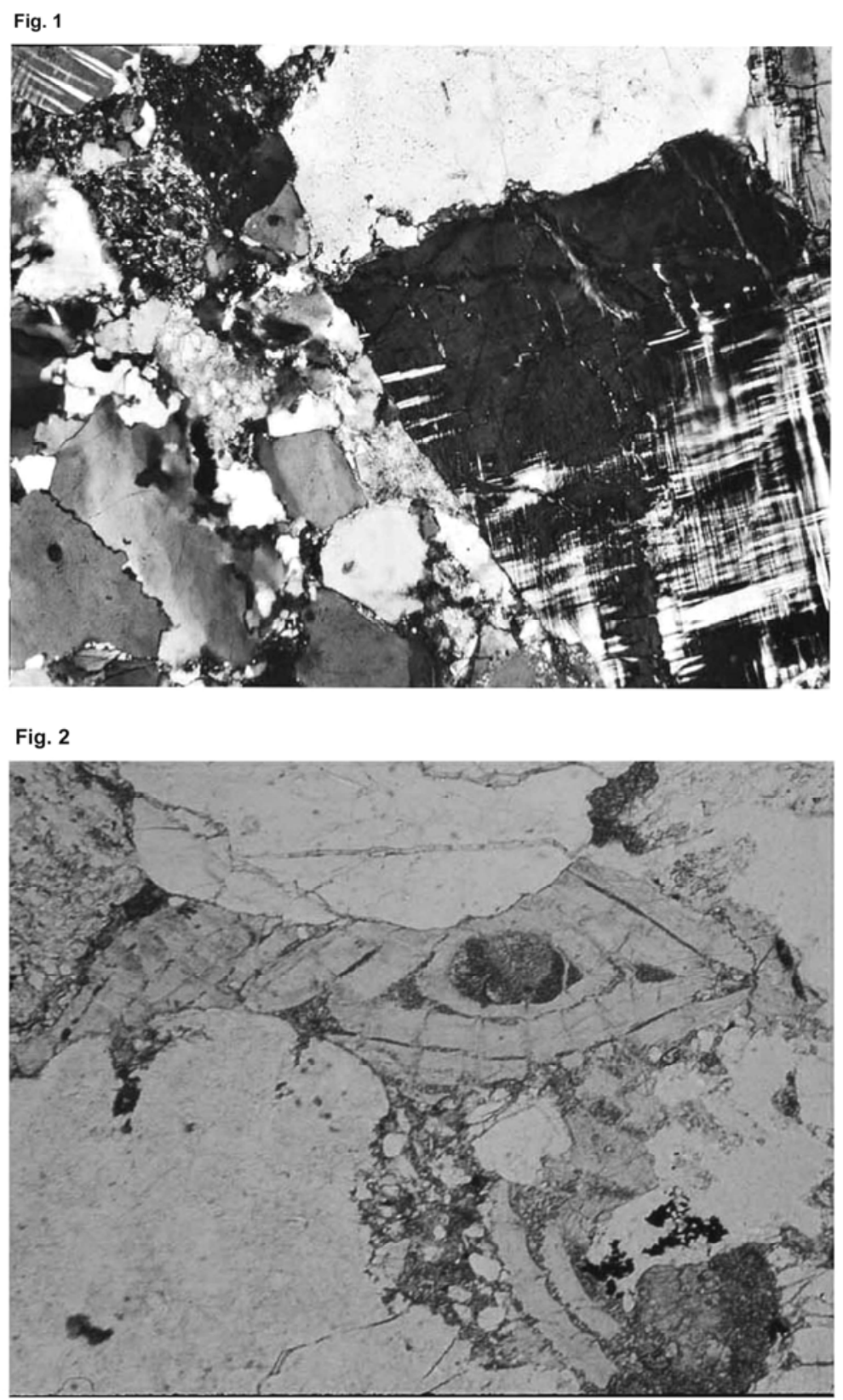
CARLO AROLDI

Plate II
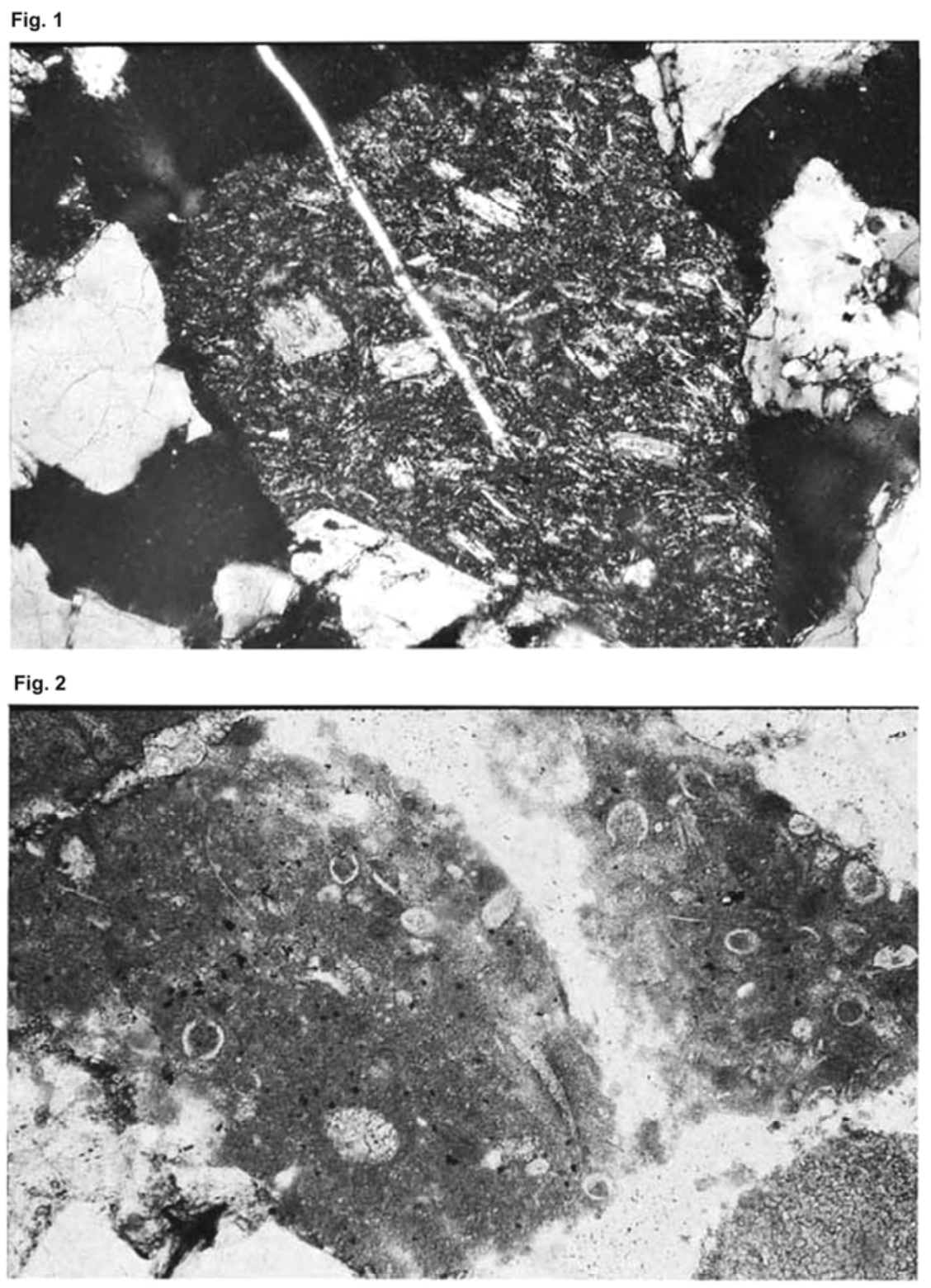